\title{
Allelopathy of extracts of Cyperus rotundus and Oxalis latifolia on snapdragon seeds germination
}

\author{
ROGÉRIO GOMES PEGO (2)*, CÍNTIA MARIA TEIXEIRA FIALHO ${ }^{(3)}$
}

\begin{abstract}
Snapdragon (Anthirrhinum majus L.) is an ornamental plant propagated by seeds and usually cultivated in beds. In production fields occur many weeds, such as Cyperus rotundus and Oxalis latifolia, which can decrease flower production by competition or releasing allelopathic components. However, there is few knowledge about the effect of these allelopathic components on snapdragon seed germination. Therefore, this study aimed to determine the allelopathic potential of aqueous extracts of $C$. rotundus and $O$. latifolia on the germination of snapdragon. For this, $10 \mathrm{~g}$ of material vegetal from whole plants of $C$. rotundus or $O$. latifolia were ground in $100 \mathrm{~mL}$ of water $\left(10 \% \mathrm{w} \mathrm{v}^{-1}\right)$. The dilutions of aqueous extracts in $75 \%, 50 \%, 25 \%$ and 0 were prepared using distilled water. The seeds were kept in paper moistened with extracts, in box gerbox-type, and conditioned in a germination chamber for 11 days. After 11 days the percentage of germination, vigor, germination speed index (GSI), percentage of abnormal seedlings and dead seeds, root length and shoot seedlings were evaluated. Extracts of C. rotundus and O. latifolia reduced the percentage of seed germination by up to $17.6 \%$ and $43.7 \%$, respectively. The vigor was reduced from $55.0 \%$ to $28.5 \%$ and IVG reduced from 27 to 12 in extracts of $O$. latifolia. The maximum of $49.5 \%$ and $35.5 \%$ of dead seeds was obtained in extracts of $O$. latifolia and C. rotundus respectively. The highest concentrations of extracts of both species altered the morphology of snapdragons seedlings reducing the length of radicle and shoot.
\end{abstract}

Keywords: Antirrhinum majus, floriculture, weeds, nutsedge, wood sorrel.

\section{RESUMO}

Alelopatia de extratos aquosos de Cyperus rotundus e Oxalis latifolia na germinação de sementes de boca-de-leão Boca de leão (Anthirrhinum majus L.) é uma planta ornamental propagada por sementes e geralmente cultivada em canteiros. Em campos de produção é comum a ocorrência de muitas plantas daninhas como, por exemplo, Cyperus rotundus e Oxalis latifolia que pode diminuir a produção de flores pela competição ou liberação de componentes alelopáticos. No entanto, pouco se conhece o efeito desses alelopáticos sobre a germinação de sementes e qualidade de plantas de boca-de-leão. Por isso, esse trabalho objetivou verificar o potencial alelopático de extratos aquosos de C. rotundus e $O$. latifolia sobre a germinação de sementes de boca-de-leão. Para isso, os extratos aquosos com $10 \mathrm{~g}$ do material vegetal fresco de C. rotundus e O. latifolia foram preparados em $100 \mathrm{~mL}$ de água $\left(10 \% \mathrm{p} \mathrm{v}^{-1}\right)$. Foram obtidas as diluições de $75 \%, 50 \%, 25 \%$ e 0 usando água destilada. As sementes foram mantidas em papel umedecido com os estratos e acondicionadas em câmara de germinação por 11 dias. Aos 11 dias foram avaliados a porcentagem de germinação, vigor, índice de velocidade de germinação (IVG), porcentagem de plântulas anormais e de sementes mortas, comprimento da raiz e da parte aérea das plântulas. Extratos de C. rotundus e O. latifolia reduziram a porcentagem de germinação de sementes em até $17.6 \%$ e $43.7 \%$, respectivamente. O vigor foi reduzido de $55.0 \%$ para $28.5 \%$ e o IVG reduzido de 27 para 12 em extratos de O. latifolia. O máximo de $49.5 \%$ e $35.5 \%$ de sementes mortas foi obtido nos extratos de O. latifolia e C. rotundus, respectivamente. As maiores concentrações de extratos de ambas as espécies alteraram a morfologia de plântulas de boca de leão reduzindo o comprimento da radícula e da parte aérea.

Palavras-chave: Anthirrhinum majus, floricultura, plantas daninhas, tiririca, trevo-azedo.

\section{INTRODUCTION}

Many ornamental species such as bellflowers, carnations, daisy, pansy and sunflower are propagated via seeds. Among these, snapdragons (Antirrhinum majus L.) has notable growing in market as cut flowers for place decoration or to gardens, however the production techniques for obtaining of high quality flowers are not established (SHAFIQUE et al., 2011; NAWAZ et al., 2017).

One of the main factors that determine agricultural production, including the production of flowers, is the presence of weeds that causing economic damage by competition for light, space, nutrients and water in addition to acting as hosts for pests and produce allelopatic

DOI: http://dx.doi.org/10.14295/oh.v24i4.1192

${ }^{(1)}$ Received in 02/05/2018 and accepted in 05/09/2018

${ }^{(2)}$ Universidade Federal Rural do Rio de Janeiro (UFRRJ), Seropédica-RJ, Brazil. *Corresponding author: engagropego@yahoo.com.br

${ }^{(3)}$ Universidade Federal dos Vales do Jequitinhonha e Mucuri (UFVJM), Diamantina-MG, Brazil.

Licensed by CC BY 4.0 
compounds (RODRIGUES et al., 2010). The allelopathic compounds have great influence on seed germination and seedling development causing quality losses on stand formation of many species (GUSMAN, 2011; HODÍ et al., 2012; RASTEGAR et al., 2016).

The most common weed species present in the field of ornamental plants are the Cyperus rotundus (purple nutsedge) and Oxalis latifolia (sour clover), often cited as causes of production losses due to competition or release of allelopathic compounds (RASTEGAR et al., 2016; QUEIROZ et al., 2016; PRASAD and SHIVAY, 2017). Both species are found in bromeliads production (RODRIGUES et al., 2007; SALA et al., 2007), but they may also be found in field of roses, chrysanthemum, gerbera, tango, lily and snapdragon.

C. rotundus is known for causing inhibition allelopathic on seed germination and seedling development of several vegetable crops such as tomatoes, lettuce, cabbage, broccoli, cauliflower, radish and mustard as well as extensive crops like maize, beans and soybeans (MUNIZ et al., 2007; ANDRADE et al., 2009). In the analysis of high performance liquid chromatography (HPLC) was observed that extracts $C$. rotund have high concentrations of phenolic allelochemicals such as caffeic acid, ferulic, coumaric, benzoic, vanelic, chlorogenic and cinnamic while the tubers had higher concentrations of hydroxybenzoic acid, caffeic, ferulic, chlorogenic and vanelic (EL-ROKIEK et al., 2010).

Few studies have been conducted to determine the effects of allelochemicals from plants of genus Oxalis, there are reports of presence of oxalic acid in leaves, stems and roots and bulbs that is responsible for the inhibition of germination of lettuce seeds and biomass production in plants tomato and oats (SHIRAISHI et al., 2005, TRAVLOS et al., 2008, HÓDI et al., 2012). Oxalic acid is also known to increase the reactive oxygen species levels and acts on programmed cell death in vegetables (LEHNER et al., 2008).

Although the economic damage caused by $C$. rotundus and Oxalis spp. on production of several agriculture crops, there are no reports of allelopathic effects of these species on seeds germination of ornamental plants. Thus, obtain knowing on harmful effects of $C$. rotundus and $O$. latifolia on seed germination of snapdragon is needed. This knowledge may contribute to future studies on interactions of weeds in the production of ornamental plants; also will be help possible bottlenecks in the production of flowers. Therefore, this study aimed to determine the potential allelopathic of aqueous extracts $C$. rotundus and $O$. latifolia on snapdragon seeds germination.

\section{MATERIAL E METHODS}

Plants of $C$. rotundus and $O$. latifolia were collected in filed production in horticulture sector, from 8:00 to 9:00 A.M. To obtain the extracts the weed plants were taken to laboratory where were weighed $10 \mathrm{~g}$ of fresh material containing all plant parts (leaves, petioles and bulbs), and ground in an industrial blender, for one minute in 100 $\mathrm{mL}$ of distilled water. The crude extract was filtered on hydrophilic cotton three times according following of a paper filter three times (GUSMAN et al., 2011; BORELA et al., 2017).

The crude extract was established as a solution composed of $100 \%$ of components extracted; from crude extract aliquots were taken to obtain extracts $75 \%, 50 \%$ and $25 \%$; all of them was used for dilution distilled water. Immediately after dilution, the extracts were used in moistening the paper germitest substrate used to seeds germination. As control, it was used germitest papers soaked in distilled water.

For germination test, snapdragon seeds were kept on paper germitest inside acrylic box gerbox-type (10x10x3 $\mathrm{cm}$ ); four replications of 50 seeds were used. The paper was moistened approximately 2.5 times their weight (weight/ volume), with each extract concentration; the maintenance of the substrate moisture throughout the experiment was carried out with distilled water, when necessary. Seed were maintained within germination chambers at $20{ }^{\circ} \mathrm{C}$ and a photoperiod of $8 \mathrm{~h}$ of white light emitted by fluorescent lamps according Rules for Seed Analysis (BRASIL, 2009). Seed germination was evaluated daily and the Germination Speed Index (GSI) was calculated by the formula proposed by Maguire (1962). The first count (vigor) was obtained by the percentage of normal seedlings obtained at seventh day (BRASIL, 2009). The final germination percentage was obtained by counting the normal seedlings observed after 11 days from the beginning of the test, it was considered normal for the seedlings that had radicle greater than 0.5 $\mathrm{cm}$ in length and shoot with leaflets expanded.

The length of radicle and shoot were evaluated using four replicates of ten normal seedlings obtained in the first count. For evaluation caliper was used, yielding values in $\mathrm{cm} /$ seedling. The analysis of plants at the first count is important to determine the allellopathic effect on high vigor seeds, with the potential to limit the expression of highest physiological quality of seedlings.

The statistical design was completely randomized with five extract concentrations $(0,25 \%, 50 \%, 75 \%$ and $100 \%$ ) and four replications using 50 seeds per replicate. The results obtained in seeds germination of each species were subjected to polynomial regression using the SAEG statistical program.

\section{RESULTS AND DISCUSSION}

The percentage of seed germination of snapdragon was significantly influenced, to $5 \%$, by progressive increment of concentrations of aqueous extracts of $C$. rotundus and $O$. latifolia. The percentage of germination decreased from $88.6 \%$ to $56.6 \%$ when germinated in extracts of $C$. rotundus, a decrease of $20.1 \%$; while the percentage of seeds germinated on extract of $O$. latifolia decreased of $71 \%$ to $40 \%$, a decrease of $43.7 \%$. 


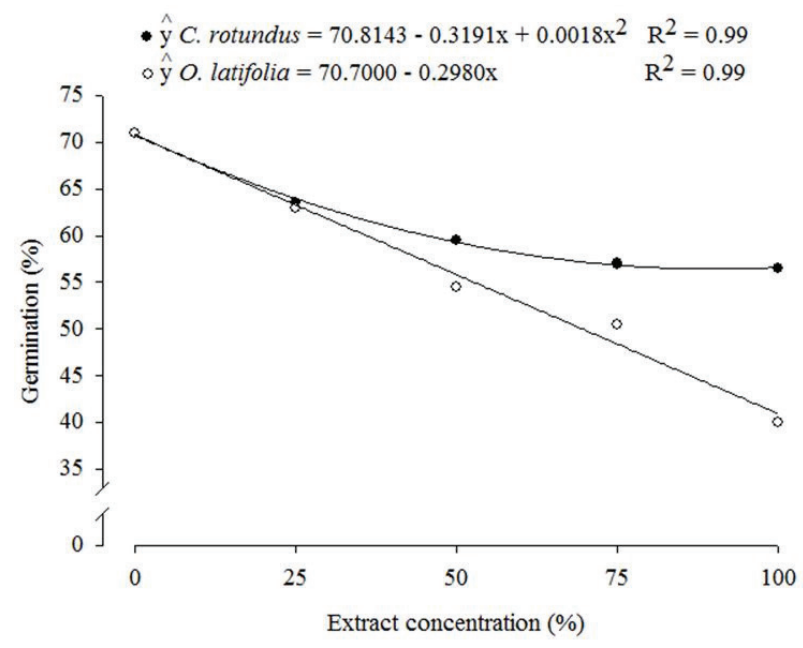

Figure 1. Percentage of seeds germination of snapdragon at concentrations of $0,25 \%, 50 \%, 75 \%$ and $100 \%$ of aqueous extracts of C. rotundus and O. latifolia.

Phenolic compounds are inhibitory allelochemicals present in leaves and bulbs of C. rotundus are responsible for inhibition of seeds germination of many species. Some studies report that these phenolic compounds act mainly on activity of enzyme involved in germination of corn, beans, soybeans, lettuce, mustard and broccoli (ANDRADE et al., 2009; HADDADCHI and GERIVANI, 2009). The main component allelochemical of $O$. latfolia is the oxalic acid, is a carboxylic acid, that reduces the seed germination of sicklepod (Cassia tora), sensitive plant (Mimosa pudica) and stinker weed (Cassia occidentalis) (SANTOS and REZENDE, 2008).

On the first count of germination at seventh day from the beginning of the germination test, there was a reduction of vigor of $56.0 \%$ to $39.5 \%$ in the germination of seeds treated with aqueous extracts of $C$. rotundus, while for seeds germinated in extracts of $O$. latifolia was observed substantial decrease in the vigor of $55.0 \%$ to $28.5 \%$ (Figure 2).

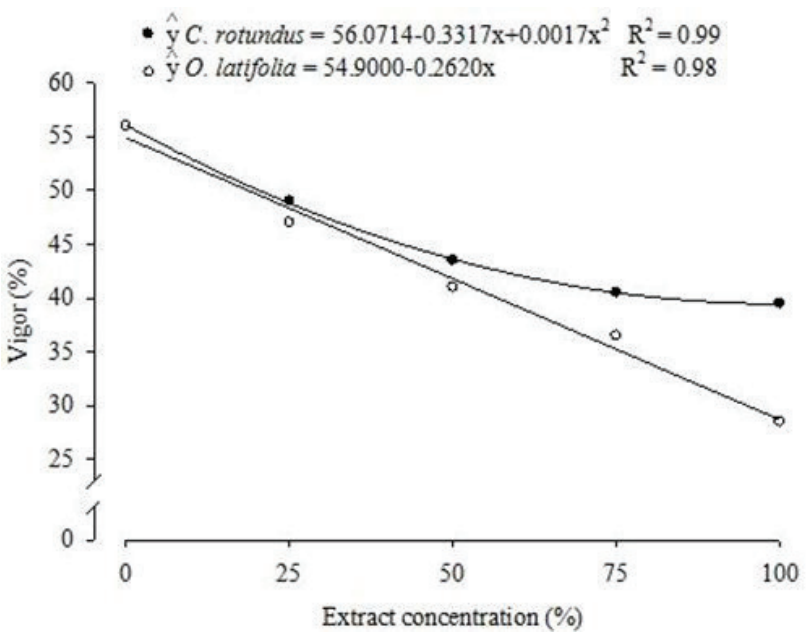

Figure 2. Vigor of seeds of snapdragon at concentrations of $0,25 \%, 50 \%, 75 \%$ and $100 \%$ of aqueous extracts of $C$. rotundus and $O$. latifolia.

The count of germination of seeds at seventh day proposed rules for seed testing is a test that provides important information of the seed vigor or the ability to snapdragon seeds has to express the maximum potential under physiological optimal conditions to germinate (BRASIL, 2009). Thus, it is possible to infer that seed snapdragon has vigor affected when germinated in aqueous extracts of $O$. latifolia, but different concentrations $C$. rotundus affected not much the seeds physiological potential. The lucerne seed germination at 5 days after initiation of germination test showed a decrease in percentage of seed germination when sown in oxalic acid solutions, the main allelochemical compound in O. lafifola, at concentrations above $7 \mathrm{mM}$ (LIATUKIENÉ et al., 2009).

The progressive increase in concentrations of the extracts of $O$. latifolia decreased the GSI of snapdragon seeds of 27 to 12 for control to maximum concentration studied (100\%) (Figure 3). The effect of concentrations on GSI was lower when seeds were treated with extract of $C$. rotundus. 


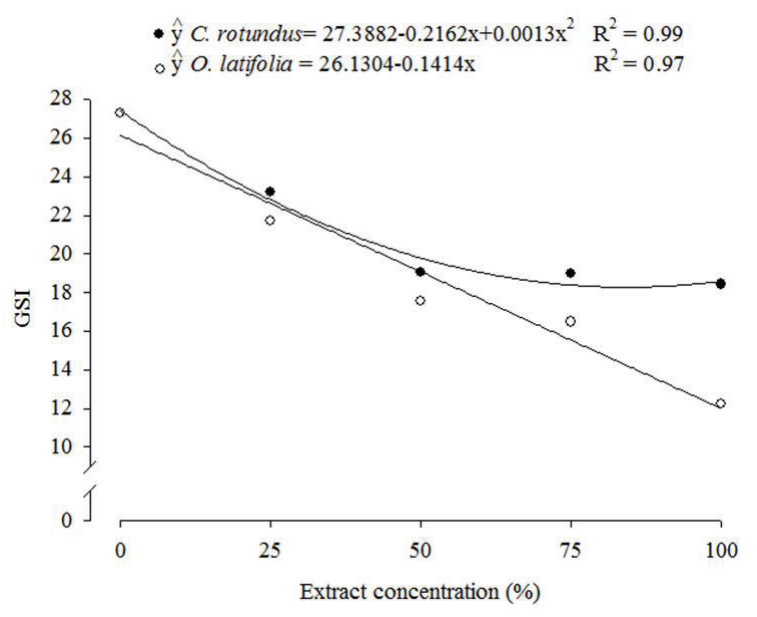

Figure 3. Germination speed index (GSI) of seeds germinated of snapdragons at concentrations of $0,25 \%, 50 \%, 75 \%$ and $100 \%$ of aqueous extracts of C. rotundus and O. latifolia.

The GSI as well as the first count is a test commonly used to evaluate the performance of seed physiological quality (MAGUIRE, 1962). Research indicate that the rate of speed of germination of lettuce seeds, a species commonly used in studies on allelopathy because of their sensitivity to many vegetable extracts, was lower in concentrations of $75 \%$ and $100 \%$ of extracts of C. rotundus (GUZMAN et al., 2011). These authors observed that increasing concentrations of the extracts of C. rotundus also reduced the rate of speed of germination of cabbage, tomato and radish.
In the results presented in this study, it was observed that the GSI of snapdragon was observed only small downward trend in extracts of $C$. rotundus while extracts of $O$. latifolia caused more significant decrease in the GSI.

High percentage of dead seeds at 11 days of evaluation was observed. We observed higher mortality of $49.5 \%$ in seed extracts of $O$. latifolia at a concentration of $100 \%$ and $36.3 \%$ in the extracts of C. rotundus diluted to $81.5 \%$ (Figure 4).

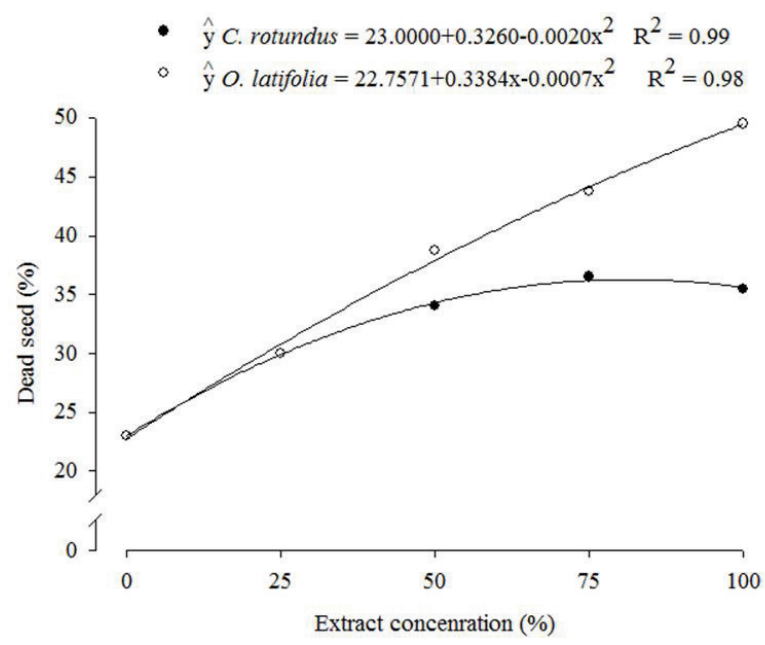

Figure 4. Percentage of Snapdragons seeds dead treated with concentrations of $0,25 \%, 50 \%, 75 \%$ and $100 \%$ of aqueous extracts of C. rotundus and O. latifolia.

The percentage of dead seeds of red clover was, reached after 5 days of the beginning of the test, of $25 \%$ when germinated in moistened paper substrate with 10 $\mathrm{mM}$ oxalic acid, but when $30 \mathrm{mM}$ oxalic acid was used all seeds were dead the same period (LIATUKIENE et al., 2009). The extracts of C. rotundus act on key enzymes active during seed hydration during soaking seeds such as amylases, endo- $\beta$-mannanase and $\beta$-glucanases activated in the embryo (GANGULI and NON-MANDI, 1993). Muniz et al. (2008) found that seeds germinated on paper moistened with extracts of $C$. rotundus showed a reduction in the activity of endo- $\beta$-mannanase in lettuce and reduction 
in the activity of amylases in maize seeds. Therefore, one of the factors that can be considered for the high percentage of dead seeds observed in this study with the snapdragons is a possible inhibition of enzymes involved in the germination process.
The percentage of abnormal seedlings obtained after 11 days of evaluation was up $10 \%$ in seeds germinated in extracts of $O$. latifolia concentrates (Figure 5). No increase of abnormal seedlings at different concentrations C. rotundus.

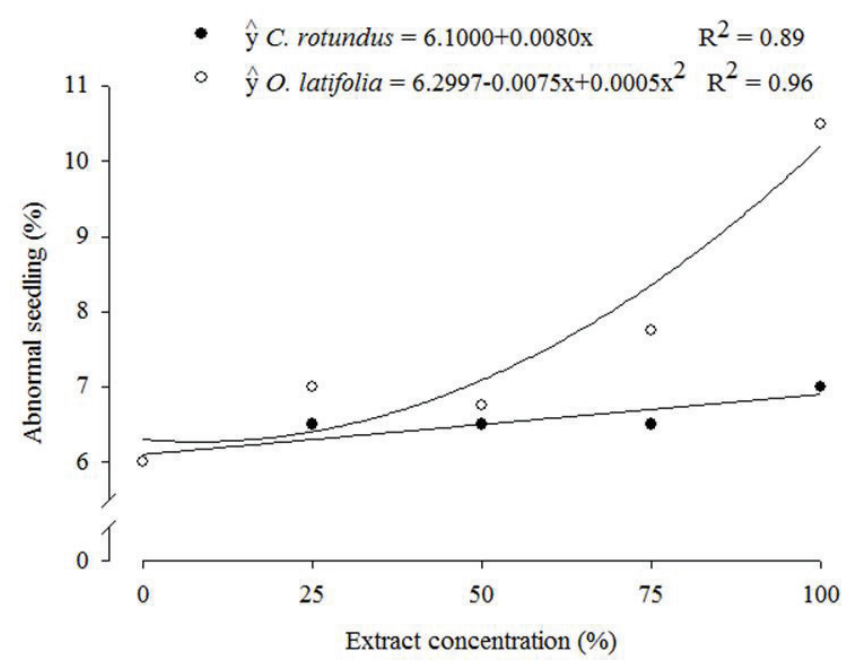

Figure 5. Abnormal seedlings snapdragon obtained from seed germination at concentrations of $0,25 \%, 50 \%$, $75 \%$ and $100 \%$ of aqueous extracts of $C$. rotundus and $O$. latifolia.

The abnormalities related to allelopathic influence on plant growth are more frequently related to the root system, as has high frequencies of atrophied roots, or damaged and in some cases these structures are competently absent (GATTI et al., 2004). It is possible that snapdragon seedlings have low sensitivity to $C$. rotundus extracts but the aqueous extracts of $O$. latifolia are responsible for the largest percentage of abnormalities. Lehner et al. (2008) found that the treating seedlings of Arabidopsis thaliana with up to 3 $\mathrm{mM}$ of oxalic acid had no impact on the growth of the plant, but deleterious effects were observed on seedling growth from a concentration of $6 \mathrm{mM}$; oxalic acid act in signal transduction leading to the death of $A$. thaliana cells, acting on active gene expression, de novo protein synthesis, cleavage of nuclear DNA, cell shrinkage and induce to increase levels reactive oxygen species. These authors also reported that seedlings tobacco exhibit sensitivity ace high concentrations of oxalic acid.

Aqueous extracts of both species inhibited the radicle of seedlings snapdragon, this effect was proportional to increasing concentrations of the extracts (Figure 6).

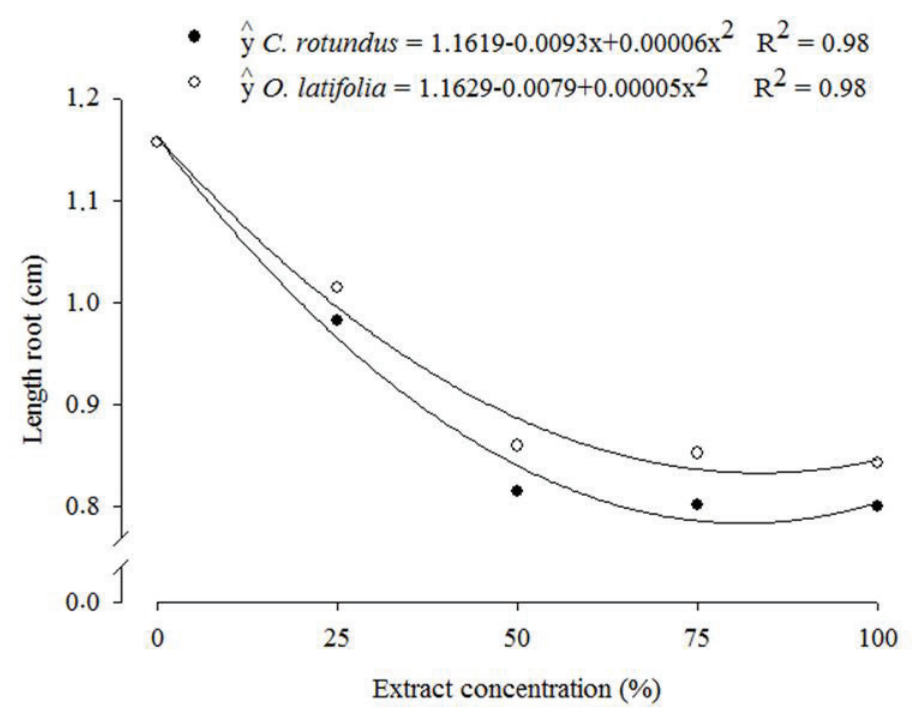

Figure 6. Seedling root length of snapdragon obtained from seed germination at concentrations of $0,25 \%, 50 \%, 75 \%$ and $100 \%$ of aqueous extracts of C. rotundus and $O$. latifolia. 
Phytotoxic effects on seed germination and early seedling growth of phenolic compounds as isocurcumenol present in extracts of $C$. rotundus, and these effects caused inhibition of root growth (ANDRADE et al., 2009). Another causes can be the reduction of peroxidase activity when seeds were germinated in substrate containing aqueous extracts, this possibly is a factor to occurrence of abnormalities in roots because this enzyme is directly involved in the modulation of growth and hypocotyl elongation of plant tissues (MUNIZ et al., 2007).

Inhibition of seedling epicotyl length of snapdragon was most intense in seedlings obtained from seed germination in extracts of $C$. rotundus this effect was proportional to increasing concentrations of the extracts (Figure 7).

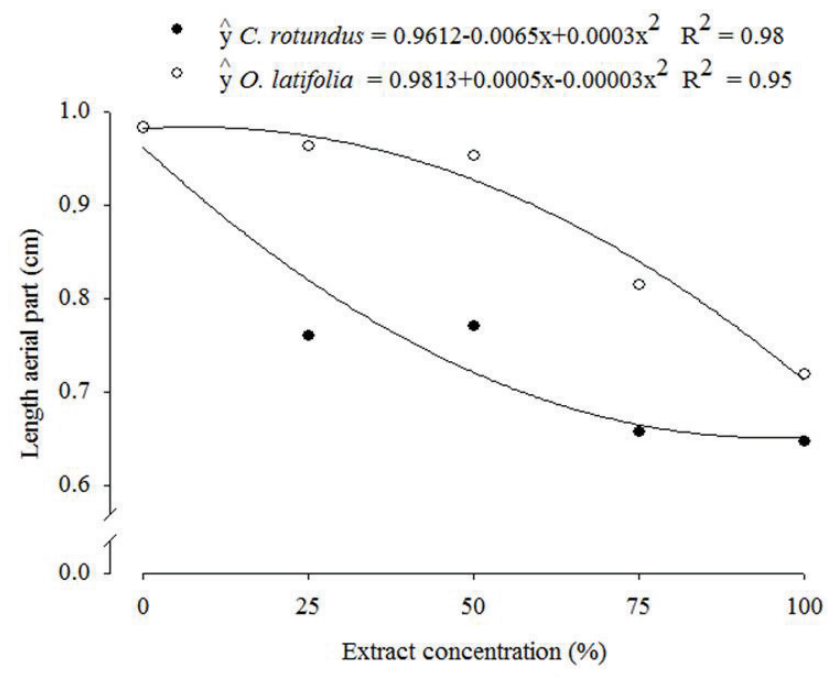

Figure 7. Length aerial part of seedlings obtained from snapdragon seed germination at concentrations of $0,25 \%$, $50 \%$, $75 \%$ and $100 \%$ of aqueous extracts of C. rotundus and $O$. latifolia.

Shiraishi et al. (2005) studied five species of Oxalis spp., and found that root exudates of these plants affect the shoot growth of lettuce seedlings, and the inhibition was to up $85 \%$. Andrade et al. (2009) working with aqueous extracts of dried leaves of $C$. torundus observed a reduction in shoot length of seedlings of various species such as lettuce, cabbage, tomato, mustard, broccoli and cauliflower.

The results presented in this search are important for future studies to produce snapdragon as well as outers ornamental plants, especially in the production of seedlings, once the weeds $C$. rotundus and $O$. latifolia drastically reduce the seeds germination and vigor and morphology seedling.

\section{CONCLUSIONS}

The aqueous extracts of $C$. rotundus and $O$. latifolia show allelophatic potential on the germination and seed vigor of snapdragon, causing decrease these variables and seeds mortality.

The highest concentrations of extracts of both change the morphology of seedlings by reducing the length of radicle and shoot, these being more intensified at the highest concentrations studied.

\section{ACKNOWLEDGEMENTS}

The authors are grateful to the Fundação de Amparo à Pesquisa de Minas Gerais (FAPEMIG) for funding this research and to Conselho Nacional de Desenvolvimento Científico e Tecnológico (CNPq) for the scholarship.

\section{AUTHORS CONTRIBUTIONS}

R.G.P. (10000-0002-2122-6442: Conception of the work, conduction of the experiment, evaluation of the experiment, data analysis and interpretation, drafting and critical revision of the article, final approval of the version to be published. C.M.T.F. ${ }^{0000-0002-1764-3921}$ : conduction of the experiment, evaluation of the experiment, data collection, data analysis and interpretation, drafting and critical revision of the article.

\section{REFERENCES}

ANDRADE A.M.; BITTENCOURT, A.H.C.; VESTENA, $\mathrm{S}$. Aleleopático potential of Cyperus rotundus L. on cultivated species. Ciência e Agrotecnologia, v.33, p.1984-1990, 2009. DOI: http://dx.doi.org/10.1590/S141370542009000700049

BORELLA, J.; LESCHEWITZ, R.; TRAUTENMÜLLER, J.W.; SILVA, D.R.O.; SCHMIDT, D. Efeito alelopático de extrato de canola (Brassica napus) sobre a fase de geminação da cultura da soja. Brazilian Journal of Biosystems Engineering, v.11, n.1, p.18-25, 2017.

BRASIL. Ministério da Agricultura, Pecuária e Abastecimento. Regras para análise de sementes. Ministério da Agricultura, Pecuária e Abastecimento. Secretaria de Defesa Agropecuária. Brasília, DF: Mapa/ 
ACS, 2009. 399p.

EL- ROKIEK, K.G.; El- DIN, S.A.S.; SHARARA, F.A.A. Allelopathic behaviour of Cyperus rotundus L. on both Chochorus olitorius (Bread leaved weed) and Echinochloa crus-galli (grassy weed) associated with soybean. Journal of Plant Protection Research, v.50, n.3, p.274-279, 2010. DOI: https://doi.org/10.2478/v10045-010-0048-7

GANGULI, S.; SEN-MANDI, S. Effects of ageing on amylase activity and scutellar cell structure during imbibition in wheat seed. Annals of Botany, v.71, n.5, p.411-416, 1993.

GATTI, A.B.; PEREZ, S.C.J.G.A.; LIMA, M.I.S. Atividade alelopática de extratos aquosos de Aristolochia esperanzae O. Kuntze na germinação e no crescimento de Lactuca sativa L. e Raphanus sativus L. Acta Botânica Brasileira, v.18, n.3, p.459-472, 2004.

GUSMAN, G.S.; YAMAGUSHI, M.Q.; VESTENA, S. Potencial alelopático de extratos aquosos de Bidens pilosa L., Cyperus rotundus L. e Euphorbia heterophylla L. Iheringia, v.66, n.1, p.87-98, 2011.

HADDADCHI, G.R.; GERIVANI, Z. Effects of phenolic extracts of canola (Brassica napuse L.) on germination and physiological responses of soybean (Glycin max L.) seedlings. International Journal of Plant Production, v.3, n.1, p.63-74, 2009.

HÓDI, A.M.; HÓDI, L.; PALKOVICS, L. Comparative study of the allelopathic effects of invasive wood sorrels (Oxalis corniculata, Oxalis dillenii Jacq.) in Hungary. Current Trends in Plant Protection-Proceedings, v.1, n.1, p.86-88, 2012.

LEHNER, A.; MEIMOUN, P.; ERRAKHI, R.; MADIONA, K.; BARAKATE, M.; BOUTEAU, F. Toxic and signalling effects of oxalic acid Oxalic acid - Natural born killer or natural born protector. Plant Signaling \& Behavior, v.3, n.9, p.746-748, 2008.

LIATUKIENE, A.; LIATUKAS, Z.; RUZGAS, V. Resistance of lucerne (Medicago spp.) germinating seeds to oxalic acid. Biologija, v.55, n.1, p.46-50, 2009.

MAGUIRE, J.D. Speed of germination-aid in selection and evaluation for seedlings emergence and vigor. Crop Science, v.2, n.1, p.176-177, 1962.

MUNIZ, F.R.; CARDOSO, M.G.; PINHO, E.V.R.V.; VILELA, M. Physiological quality of maize seed, bean, soybean, and lettuce in the presence of purple nutsedge extracts. Revista Brasileira de Sementes, v.29, n.2, p.195-204, 2007.

NAWAZ, M.A.; SHAFIQUE, A.; SILVA, J.A.T.; AHMED, W.; SALEEM, B.A. Planting time affects vegetative and reproductive growth of exotic cultivars of snapdragon (Antirrhinum majus L.). International Journal of
Agriculture \& Biology, v.19, n.1, p.23-28, 2017.

PRASAD, R.; SHIVAY, Y.S. Oxalic acid/oxalates in plants: from self-defense to phytoremediation Current Science, v.112, n.8, p.1665-1676, 2017.

QUEIROZ, J.R.G.; SILVA JR., A.C.; MARTINS, D. Herbicide selectivity in tropical ornamental species. Planta Daninha, v.34, n.4, p.795-801, 2016. DOI: http://dx.doi. org/10.1590/s0100-83582016340400020

RASTEGAR, S.; AHMADZADEH, M.; PIROOZY, H. Allelopathic potential of the extract from six ornamental spices on germination and seedling growth of marigold (Calendula officinalis). Iranian Journal of Seed Research, v.2, n.2, p.149-158, 2016.

RODRIGUES, I.M.C.; FERREIRA, F.A.; GROSSI, J.A.S.; BARBOSA, J.G.; PAULA, C.C.; REIS, M.R. Occurrence of weeds in the cultivation of bromeliads. Planta Daninha, v.25, n.4, p.727-733, 2007. DOI: http://dx.doi.org/10.1590/ S0100-83582007000400009

SALA, A.; VERDAGUER, D.; VILA, M. Sensitivity of the invasive geophyte Oxalis pes-caprae to nutrient availability and competition. Annals of Botany, v.99, n.4, p.637-645, 2007.

SANTOS, S.; REZENDE, M.O.O. Potential herbicide evaluation of secondary compounds in the germination of weed seeds found in pastures. Analytica, v.32, n.4, p.32:72-78, 2008.

SHAFIQUE, A.; MAQBOOL, M.; NAWAZ, M.A., AHMED, W. Performance of various snapdragon (Antirrhinum majus L.) cultivars as cut flower in punjab, pakistan. Pakistan Journal of Botany, v.43, n.2, p.10031010, 2011.

SHIRAISHI, S.; WATANABE, I.; KUNO, K.; FUJII, Y. Evaluation of the allelopathic activity of five Oxalidaceae cover plants and the demonstration of potent weed suppression by Oxalis species. Weed Biology and Management, v.5, n.3, p.128-136, 2005.

TRAVLOS, I.S.; PASPATIS, E.; PSOMADELI, E. Allelopathic potential of Oxalis pes-caprae tissue and root exudates as a tool for integrated weed management. Journal of agronomy, v.7, n.2, p.202-205, 2008.

TUR, C.M.; BORELLA, J.; PASTORINI L.H. Allelopathy of aqueous extracts of Duranta repens on the germination and early growth of Lactuca sativa and Lycopersicum esculentum. Biotemas, v.23, n.2, p.13-22, 2010. 